\title{
Transformasi LPP TVRI di Tengah Pergolakan Politik dan Struktural
}

\author{
Retno Intani \\ Anggota Dewan Pengawas LPP TVRI Periode 2006-2011; \\ Dosen di Universitas Moestopo
}

\begin{abstract}
TVRI still faces an identity crisis between representing the public interest with the interests of power. The influence of power remains strong even though TVRI has been established as public service broadcasting since 2002. This article tries to analyze the political and structural issues that interfere the transformation of TVRI as public service broadcasting. Various conflicts of interest, especially from the government and parliament eventually obstruct TVRI to act as a public broadcaster in the real sense.
\end{abstract}

Keywords: TVRI, public service broadcasting, political and structural agitation.

\begin{abstract}
Abstrak
TVRI masih mengalami krisis identitas antara menjadi representasi publik atau melayani penguasa. Kekuasaan masih sangat berpengaruh pada lembaga ini meski TVRI telah ditetapkan sebagai lembaga penyiaran publik (LPP) sejak tahun 2002. Artikel ini mencoba menganalisis isu-isu politik dan struktural yang menghambat transformasi TVRI menjadi LPP. Beberapa problem kepentingan terjadi, terutama dari pihak pemerintah dan DPR yang ternyata menghambat lajunya transformasi TVRI dalam proses menjadi badan penyiaran publik.
\end{abstract}

Kata Kunci: TVRI, lembaga penyiaran publik, pergolakan dunia politik dan struktural

\section{Pendahuluan}

TVRI telah ditetapkan sebagai Lembaga Penyiaran Publik (LPP) di Indonesia, tapi hingga saat ini operasionalisasi penyelenggaraan LPP belum terlihat. Dalam kaitan ini, Ashadi Siregar (2001) menjelaskan beberapa hal yang perlu diperhatikan berkaitan dengan keberadaan media penyiaran publik di Indonesia, yaitu telekomunikasi sebagai basis material, orientasi fungsi publik sebagai basis kultural, sistem jaringan publik, adanya code of conduct profesi dan institusi serta sistem kontrol fungsi publik. Basis kultural keberadaan media penyiaran publik sebagai institusi publik ditentukan oleh nilai bersama yang menjadi dasar keberadaannya. Dalam konteks ini, kebersamaan sebagai nilai dasar ini dimulai dari ketentuan hukum, kebijakan negara, serta konsensus yang tumbuh di lingkungan masyarakat tentang orientasi dan fungsi sosialkultural yang harus dijalankan oleh media penyiaran publik. 
Nilai kebersamaan inilah yang diharapkan dapat dirumuskan oleh pengelola penyiaran publik sebagai titik awal dalam penghayatan atas orientasi fungsional kelembagaan. Keterlibatan publik dalam pengaturan alokasi frekuensi dan dunia penyiaran pada akhirnya diharapkan akan mewujudkan diversity of ownership dan diversity of content dalam bingkai demokratisasi penyiaran (Siregar, 2011).

Selain independen dan imparsial, lembaga penyiaran publik juga berorientasi pendidikan kewargaan, pengembangan budaya, kesenian, ilmu pengetahuan, kreativitas dan inovasi, serta problem solving terhadap masalah bersama (Gazali, 2002). Oleh karenanya, lembaga penyiaran publik idealnya dibiayai oleh publik atau Negara. Kemudian, oleh karena wilayah negara Indonesia cukup luas, lembaga penyiaran publik harus berdaya pancar luas (nasionalatau regional secara menyeluruh).

Untuk mendukung keseluruhan fungsi dan peran lembaga penyiaran publik, keterlibatan masyarakat dalampenyusunan program mutlak diperlukan, diperlukan adanya organ yang mewakili masyarakat. Dengan demikian, terdapat representasi publik yang akan menampung aspirasi kebutuhan-kebutuhan masyarakat untuk diprogramkan dalam siaran-siaran di lembaga penyiaran publik dan tidak berpatokan pada rating. Riset independen yang diorientasikan untuk mengidentifikasi kebutuhan TV publik juga sangat dimungkinkan sehingga akan memberi garis pembatas yang tegas dengan lembaga penyiarankomersial.

TVRI sejatinya menjadi tumpuan harapan masyarakat untuk menjadi media pemberdayaan masyarakat. Signifikansi TVRI sebagai penyiaran publik juga sangat terasa ketika belakangan ini kita selalu menghadapi krisis informasi publik saat muncul berbagai masalah seperti tsunami, banjir, gempa bumi, tanah longsor, flu burung, busung lapar dan lain-lain. Komunikasi publik dan diseminasi informasi dari pemerintah menghadapi berbagai masalah. Akibatnya, masyarakat praktis hanya tergantung pada media untuk mendapatkan informasi yang dibutuhkan. Media komersial tidak optimal menjalankan fungsi komunikasi publik karena terikat hukum komersialisasi dan komodifikasi. Oleh sebab itu, penyiaran publiklah yang paling ideal untuk melaksanakan fungsi-fungsi tersebut.

Menurut Moelyono (2004), sebagai TV publik, TVRI merupakan TV alternatif dengan berbagai program yang berbeda dan bermanfaat dibanding dengan TV swasta. TV publik menjangkau khalayak di pelosok-pelosok desa yang tidak terjangkau oleh TV swasta karena pada umumnya TV Swasta hanya menjangkau perkotaan. Dengan demikian, TVRI dapat melakukan pencerahan terhadap khalayak 
pemirsanya dengan acara-acaranya yang khas tanpa harus bersaing dengan TV swasta yang sudah ada. Namun, sejak awal pembentukannya, TVRI memang tidak dirancang secara khusus untuk melaksanakan peran dan fungsi sebagai lembaga penyiaran publik.

Manifestasi TV publik di Indonesia seperti yang tertuang di dalam Undang Undang No 32 Tahun 2002 adalah melalui TVRI. Namun, kurang lebih satu dekade sejak penetapannya sebagai lembaga penyiaran publik, TVRI masih mengalami krisis identitas antara mewakili kepentingan publik dengan kepentingan pemerintah ataupun penguasa. Ini terjadi karena banyak faktor, diantaranya masih kuatnya pengaruh kekuasaan.

Pada era Orde Lama, TVRI merupakan bagian proyek "mercusuar" pemerintahan Presiden Soekarno. Pada waktu itu, harga-diri bangsa di mata dunia luar menjadi prioritas utama, melebihi kebutuhan-kebutuhan riil yang lain dari bangsa Indonesia, dan TVRI, pada akhirnya, tidak bisa dilepaskan dari proyek itu.

Pada era Presiden Soeharto, TVRI adalah medium propaganda politik ke luar dan dalam negeri, serta medium konsolidasi pemegang kekuasaan dan monopoli informasi oleh Jakarta.'TVRI

1 Studi tentang televisi, khususnya TVRI secara detail dan lengkap dapat dilihat di Philip Kitley, Konstruksi Budaya Bangsa di Layar Kaca. dikendalikan oleh pemerintah melalui Departemen Penerangan dan berfungsi menjadi corong pemerintah.

Reformasi tahun 1998 mengubah drastis kedudukan TVRI. Departemen Penerangan yang selama itu memayungi operasional TVRI dibubarkan oleh presiden Gus Dur pada tahun 1999. Tumbangnya pemerintahan Orde Baru, juga menandai berakhirnya status TVRI (dan $R R I$ ) sebagai anak emas pemerintah. Kemampuan finansial pemerintah untuk menopang sustainabilitas TVRI semakin berkurang karena krisis moneter. Selanjutnya, perubahan-perubahan status hukum TVRI juga memperkuat alasan pemerintah untuk memperlakukan TVRI layaknya televisi swasta, yakni mandiri secara finansial sehingga tidak perlu banyak disubsidi seperti sebelumnya. Pengurangan subsidi tersebut ternyata, dalam perkembangannya, sangat mengganggu perjalanan TVRI.

Masalah berikutnya yang tidak kalah peliknya adalahkonflik manajemen yang tak berujung. Pemerintahan telah berganti, kondisi politik telah banyak berubah, tapi tidak demikian dengan hikayat TVRI sebagai lembaga yang rentan intervensi politik. Di satu sisi, pemerintah tetap menganggap TVRI sebagai instrumen politik untuk menyukseskan program-program pemerintah. Hal itu tampak, salah satunya, pada saat Direksi LPP TVRI

LSPP, ISAI dan PT Media Lintas Inti Nusantara, 2001. 
2006-2011 berakhir masa tugasnya. Menkominfo mengambil alih tugas Dewan Pengawas untuk memperpanjang tugas Dewan Direksi. Padahal, secara hukum, hal itu bertentangan dengan PP 13/2005 tentang TVRI yang menyatakan bahwa pengangkatan dan pemberhentian Direksi merupakan kewenangan dan tanggung jawab Dewan Pengawas. Di sisi lain, memberikan peranan lebih besar kepada DPR untuk menentukan nasib TVRI sama artinya dengan mengundang partai-partai politik untuk menancapkan pengaruhnya terhadap TVRI. Ini bisa dilihat dari kuatnya persaingan politik yang selalu mewarnai restrukturisasi TVRI. Partai politik selalu berkepentingan dengan suksesi dalam tubuh TVRI. Bahkan, sekelompok anggota Komisi 1 DPR RI periode 20092014 yang membawahi Pokja TVRI pun cenderung mengabaikan substansi pengembangan TVRI sebagai lembaga penyiaran publik, dan lebih memfokuskan pada suksesi kekuasaan di TVRI. ${ }^{2}$

Berangkat dari beragam persoalan inilah, tulisan ini ingin menganalisis secara tajam pergolakan-pergolakan politik dan struktural yang mengganggu TVRI untuk menstransformasikan dirinya sebagai lembaga penyiaran publik. Melalui analisis ini, diharapkan segala persoalan politik dan struktural yang menghimpit TVRI bisa dibahas dengan

\footnotetext{
2 Notulensi-notulensi Rapat Dengar Pendapat (RDP) Dewan Pengawas LPP TVRI 2006-2011 dengan Komisi 1 DPR RI
}

tajam sehingga persoalan-persoalan struktural itu lebih bisa dipetakan dengan baik.

\section{Tarikan Beragam Kepentingan}

Realisasi bentuk-bentuk lembaga penyiaran di Indonesia terutama yang berbasis pada kepentingan publik tidak hanya mampu diwujudkan melalui penetapan Undang-Undang. Interaksi riil dalam struktur sosial yang kompleks menentukan realisasinya (Rahayu, 2003:22). Jika secara prinsipil telah memenuhi syarat, maka pelembagaan penyiaran publik di Indonesia tampaknya belum dimaknai sama oleh para pemangku kepentingan. Pemaknaan TVRI sebagai lembaga penyiaran publik oleh para pemangku kepentingan masih dalam proses pencarian.

\section{Sikap Pemerintah dan DPR}

$$
\text { Dedy N.Hidayat (2001) }
$$

mengemukakan dalam penerapan TVRI sebagai TV Publik, menghadapi masalah dengan kemungkinan dimanfaatkannya akses publik oleh kelompok-kelompok politik ataupun kelompok sosial tertentu. Pergulatan politik dan struktural telah terjadi dalam pelembagaan TVRI sebagai lembaga penyiaran publik manakala kepentingan-kepentingan politik pragmatis mulai merambah kepengurusan TVRI. Hal itu terlihat pada kecenderungan atau kebiasaan pemerintah dan DPR untuk mengintervensi urusan-urusan TVRI. Intervensi politik selalu menjadi 
menu sehari-hari TVRI di masa lalu ketika secara langsung berada di bawah kontrol Departemen Penerangan. Namun, intervensi politik itu ternyata tidak hilang ketika TVRImemasuki era reformasi dan berubah status menjadi lembaga penyiaran publik. Jika pada Orde Baru intervensi politik terhadap TVRI bersifat langsung, tegas dan memusat kepada campur tangan Departemen Penerangan, intervensi politik terhadap TVRI pada masa reformasi bersifat tidak langsung, di bawah permukaan, tapi dapat dilakukan oleh banyak pihak: menteri, presiden dan jajaran maupun pejabatnya, DPR, anggota DPR atau Partai Politik.

Intervensi tersebut seolah-olah tidak mempedulikan perubahan status TVRI dari televisi pemerintah menjadi lembaga penyiaran publik. Pemerintah dan DPR masih terus menghadapi TVRI dengan cara berpikir yang hierarkhisfeodal. Pemerintah dan DPR selalu merasa berpiutang budi kepada TVRI karena merekalah yang berperan dalam menyetujui anggaran tahunan TVRI serta dalam menyeleksi dan menetapkan anggota Dewan Pengawas TVRI. Pemerintah dan DPR juga selalu berpikir hierarkhis-struktural dengan menempatkan TVRI seperti layaknya BUMN atau instansi lain yang secara langsung di bawah kontrol pemerintah dan DPR. Bahkan, pemerintah dan DPR pun terjebak dalam dogma bahwa TVRI itu perusahaan, yang membuat Dewan Pengawas dianggap sebagai Komisaris. Ini jelas tidak sesuai dengan PP 11 dan 13/2005. Pemerintah dan DPR juga berpikir feodal, yakni ketika dengan sadar atau tidak sadar selalu menempatkan diri sebagai pembina TVRI, paralel dengan situasi pada era Orde Baru dimana pemerintah melalui Departemen Penerangan selalu menempatkan diri sebagai pembina TVRI.

Dalam latarbelakang sejarah yang demikian, DPR dan Pemerintah selalu merasa bahwa intervensi politik terhadap TVRI adalah suatu kelaziman. Oleh karena itu, kepentingan politik selalu tidak dapat dilepaskan dari setiap momentum penting perjalanan TVRI sebagai lembaga penyiaran publik sekalipun terjadi pergantian Dewan Pengawas atau Dewan Direksi, penentuan anggaran tahunan, kebijakan soal kepegawaian, politik pemberitaan, pengadaan barang-barang kebutuhan dan lain-lain. Jabatan strategis TVRI selalu diperebutkan seperti ketika partai-partai politik juga memperebutkan pemangku jabatan-jabatan strategis BUMN dan lembaga negara yang lain.

Pada saat peresmian pemancar televisi digital TVRI di Auditorium TVRI, (Selasa 21 Desember 2010), misalnya, Presiden Susilo Bambang Yudhoyono pernah meminta agar TVRI dapat menjaga netralitas dalam pemberitaan. Netralitas di sini dijelaskan presiden sebagai memberitakan secara seimbang antara yang baik dan buruk. 
TVRI sebagai Lembaga Penyiaran Publik harus bisa fair, dan berimbang agar rakyat mendapatkan kebenaran yang sejati....Jangan yang diangkat hanya jelek-jelek saja, agak malu mengangkat yang baik. Sebagai lembaga penyiaran angkat dua-duanya untuk pendidikan. ${ }^{3}$

Presiden mengakui saat ini masih ada kekurangan dan kelemahan dalam pemerintahan. Namun, Presiden menilai pemberitaan berkaitan dengan capaian dan yang dilakukan pemerintah dan yang lain juga harus mendapat porsi pemberitaan yang sama. Termasuk juga pemberitaan di tingkat provinsi, kabupaten dan kota.

Pernyataan Presiden SBY di atas menarik untuk dikaji. Pernyataanpernyataan itu mengindikasikan bahwa Presiden berharap TVRI sebagai lembaga penyiaran publik harus bersifat fair, memberitakan baik keburukan maupun kebaikan pemerintah. Presiden berharap agar pers tidak hanya menjelek-jelekkan pemerintah. Meskipun sedikit emosional, pernyataan Presiden ini sebenarnya positif dan proporsional atau pada tempatnya. Pers yang profesional memang harus selalu memberikan kritik terhadap kelemahan-kelemahan pemerintah, tapi juga harus terbuka

\footnotetext{
${ }^{3}$ Dokumen TVRI Siaran Langsung Peresmian Siaran Digital 21 Desember 2010 pk. 14.00 WIB dan artikel "Presiden Minta TVRI Jaga Netralitas", Tempointeraktif. Diakses 21 Desember 2010.
}

memberikan apresiasi terhadap prestasiprestasi pemerintah.

Harapan Presiden agar TVRI dapat menjaga optimisme bangsa Indonesia untuk memecahkan masalahmasalahnya juga sudah pada tempatnya karena kurang-lebih demikianlah salahsatu fungsi lembaga penyiaran publik, yakni membantu masyarakat menyelesaikan masalah-masalahnya. Namun,perlu digarisbawahi bahwa seruan Presiden tersebut sebenarnya lebih tepat ditujukan kepada media komersial atau pers pada umumnya, bukan kepada TVRI. Ini karena kebiasaan “menjelek-jelekkan pemerintah" itu secara faktual saat ini bukan problem TVRI, tetapi problem media-media komersial. Secara pemberitaan, justru masih muncul penilaian dan penelitian yang menyatakan bahwaTVRI masih cenderung menyuarakan kepentingan pemerintah. Jadi, yang terjadi dalam momentum di atas bahwa Presiden memanfaatkan agenda resmi TVRI untuk menyampaikan kritik secara tidak langsung kepada media massa komersial.

Kombinasi harapan kepada TVRI dan kritik terhadap pers umum ini secara konsisten juga muncul dalam pernyataanpernyataan pemimpin pemerintahan yang lain. Pernyataan Wakil Presiden Republik Indonesia (2004-2009) Jusuf Kalla dalam peringatan hari ulang tahun ke 46 TVRI, 24 Agustus 2008, adalah salahsatunya. Dalam kesempatan itu, Jusuf Kalla menekankan pentingnya perubahan dan 
perbaikan kinerja TVRI di tengah arus ketat persaingan dengan televisi swasta saat ini. Ditegaskan bahwa pemerintah memberi kesempatan selama dua tahun bagi TVRI untuk melakukan perbaikan program agar lebih diminati oleh masyarakat. 4 Jusuf Kalla melanjutkan pernyataannya sebagai berikut.

Mari kita buat program dua tahun untuk itu. Ciptakan program 'reward and punishment' bagi karyawan. Reporter yang baik yang membuat 'angle' pemberitaan yang baik diberi bonus. Kita tunggu dua tahun, kita lihat siapa yang berhasil, kita datangi dan kita beri penghargaan.

Hal yang penting untuk digarisbawahi adalah pernyataan Jusuf Kalla berikutnya. Wapres menekankan pentingnya TVRI menjadi penyeimbang bagi pemberitaan "brutal" dari televisitelevisi swasta di mana aksi-aksi demonstrasi yang terjadi di berbagai daerah dari tingkat desa hingga ibukota sering mendominasi pemberitaan. Wapres menyatakan bahwa TVRI harus dapat membantu menciptakan ketenangan masyarakat, dengan pemberitaan dari sudut pandang berbeda. Lebih lanjut, Wapres Jusuf Kalla menjelaskan sebagai berikut.

Harus timbul pemahaman, berita lokal tetap di level lokal, tidak usah diangkat ke tingkat nasional. Maraknya berita demo memberi kesan bangsa kita itu bangsa

\footnotetext{
${ }^{4}$ Dokumen Siaran Langsung HUT TVRI Ke 46 - 24 Agustus 2008 \& "Wapres: Dua Tahun Bagi Perbaikan Program TVRI', Antaranews. Diakses 24 Agustus 2008.
}

pemarah. Kalau `imej`Indonesia jelek, pengusaha akan takut untuk melakukan investasi di sini. Kalau sudah begitu, tidak ada lagi yang pasang iklan, televisi juga dirugikan.5

Apa yang disampaikan Wapres Jusuf Kalla ini sebangun dengan pernyataan Presiden SBY di atas, yakni gabungan antara kritik terhadap pers umum yang selalu menjelek-jelekkan pemerintah atau terus-menerus menyiarkan berita-berita negatif tentang kondisi tanah air dengan harapan agar TVRI dapat menjadi penyeimbang dari kecenderungan tersebut. Mengutip istilah Jusuf Kalla, TVRI harus dapat membantu menciptakan ketenangan masyarakat dengan pemberitaan dari sudut pandang berbeda. Sayangnya tidak ada penjelasan lebih lanjut, apakah yang dimaksud dengan sudutpandang yang berbeda itu? Apakah TVRI harus menggunakan sudut pandang pemegang kekuasaan atau cukup menggunakan sudut-pandang yang netral dan tidak berorientasi kepada komodifikasi konflik?

Jawabannya atas pernyataan itu bisaditemukan dalam pernyataan Jusuf Kalla pada kesempatan yang lain. Saat "Soft Launching" TV digital TVRI di Gedung TVRI, Jakarta, Rabu, 13 Agustus 2008, Jusuf Kalla menegaskan meski menjadi stasiun televisi milik pemerintah dan dibiayai oleh negara, TVRI tetap diperbolehkan kritis sejauh tidak sampai terus-menerus menyudutkan pemerintah.

${ }^{5}$ Ibid. 
Menurut Kalla, "Inovasi boleh, tetapi dalam batas pemerintah. Jangan hantam terus pemerintah. Jadi, kritis dalam batasan itu". ${ }^{6}$ Meskipun ada kesalahan dalam mengidentifikasi TVRI sebagai televisi milik pemerintah, tapi pernyataan Jusuf Kalla tadi menjelaskan sesuatu yang sangat penting bahwa tidak ada larangan untuk TVRI bersikap kritis terhadap pemerintah, sejauh tidak bersifat menghantam terus-menerus.

Hal yang bisa disimpulkan dari paparan di atas bahwa konstruksi berpikir kalangan pemerintah tentang TVRI mengandung bias penyiaran komersial atau sebaliknya bias penyiaran pemerintah. Ketika berbicara tentang TVRI, kalangan pemerintah selalu menampilkan dikotomi antara media yang mengritik pemerintah dan media yang diharapkan dapat membantu pemerintah, antara media yang secara struktural berada di bawah intervensi pemerintah dengan media yang secara struktural berada di luar jangkauan intervensi pemerintah. Dengan kata lain, kalangan Pemerintah belum bisa melepaskan diri dari dikotomi media komersial dan media pemerintah. Tanpa banyak disadari, pemerintah masih terhegemoni pandangan yang hanya mengenal dua jenis lembaga penyiaran, yakni pemerintah dan nonpemerintah.

\footnotetext{
${ }^{6}$ Siaran Langsung Soft Launching TV digital TVRI dari Gedung TVRI, Jakarta, Rabu, 13 Agustus 2008 pk 13.00 WIB\& artikel "JK: TVRI Boleh Kritis Asal...”, Inilah.com.Diakses 13 Agustus 2008.
}

Pandangan dikotomis ini demikian menstruktur dalam pernyataanpernyataan kalangan pemerintah sehingga ketika seseorang pejabat negara bicara tentang TVRI sebagai lembaga penyiaran publik, yang ada dibenaknya sebenarnya adalah pengalaman atau pengetahuan tentang lembaga penyiaran memiliki subordinatif-organik terhadap pemerintah. Alam bawah sadar pejabat pemerintahan selalu hanya membedakan antara media milik pemerintah dan media komersial tanpa terkecuali ketika berbicara tentang lembaga penyiaran publik dan lembaga penyiaran komunitas. Hal ini bisa dimaklumi karena konsep lembaga penyiaran publik memang sebuah konsep yang baru bagi Indonesia. Sementara sudah berpuluh-puluh tahun, bangsa Indonesia hanya mengenal dua jenis media, yakni media milik pemerintah dan media komersial.

Dalam perkembangan selanjutnya, pemerintah ternyata tidak sekedar menginginkan agar TVRI tidak ikutikutan pers umum yang cenderung hanya menjelek-jelekkan pemerintah, tetapi juga menginginkan agar TVRI menjadi televisi pemerintah lagi seperti di masa lalu. Mulai akhir 2009, keinginan untuk mengembalikan status TVRI sebagai televisi pemerintah itu semakin jelas. Dalam momentum ulang tahun Lembaga Kantor Berita Antara ke 72 di Jakarta, Senin 14 Desember 2009,Wakil Presiden Boediono menginginkan tiga media milik negara, Televisi Republik Indonesia 
(TVRI), Radio Republik Indonesia (RRI) dan Lembaga Kantor Berita Nasional Antara untuk bersinergi.7

Dalam kesempatan itu, awalnya, Wapres Boediono berbicara tentang sejarah Antara yang usianya lebih lebih tua dari usia Republik Indonesia, adalah bagian dari perjuangan Republik Indonesia. Dari segi sejarahnya, Antara harus mempunyai idealisme, tidak boleh mencari sumbangan. Mengutip pernyataan Presiden pertama Republik Indonesia, Soekarno, ada dua sumbangan yang harus dimiliki LKBN Antara untuk Indonesia, yakni sebagai sarana perekat bangsa dan sebagai media untuk menyampaikan Indonesia ke dunia. Oleh karena itu, Antara harus mempunyai visi dan misi sebagai perekat bangsa dan sebagai media negara. Boediono melanjutkan, saat ini, kekuatan pasar sangat dominan dalam kehidupan pers Indonesia. Kalau media seluruhnya diserahkan ke pasar, tidak tepat karena ada visi-misi negara yang harus disampaikan.

Negara mempunyai kepentingan menyampaikan hal yang mendesak kepada rakyat, misalnya, pendidikan dan kesehatan. Dua sektor ini kurang menjadi perhatian media swasta. Selanjutnya, Wapres Boediono menegaskan perlunya

\footnotetext{
7 "'Sekarang berbagai pihak sedang membangun kekuatan untuk menyaingi negara,' ujar Boediono." Boediono: Sinergi TVRI-Antara Imbangi Swasta"

Vivanews.Diakses14 Desember 2009, 12:01 WIB
}

sinergi antara unit-unit bidang media yang dimiliki oleh Negara, dalam hal ini RRI, TVRI dan Antara. Wapres mengharapkan agar ketiganya bisa melakukan sinergi yang baik untuk mendukung visi dan misi Negara.

Sementara, negara sendiri punya RRI, TVRI, dan Antara. Namun ketiga lembaga ini berjalan sendiri, sehingga membuat media swasta yang bersinergi dalam berbagai platform sangat kuat. Sekarang berbagai pihak sedang membangun kekuatan untuk menyaingi Negara. Karena itulah, perlu ada sinergi TVRI, RRI dan Antara. Bukan untuk mendominasi, tapi untuk membuat imbangan yang pas. Kita punya unit-unit yang bisa disatukan atau disinergikan. ${ }^{8}$

Selanjutnya, dalam acara Peresmian Pemancar TV digital LPP TVRI di Jakarta, Batam, dan Surabaya di Auditorium LPP TVRI Jakarta (21/12/2010), Menkominfo Tifatul Sembiring menyatakan harapan pemerintah agar LPP TVRI mampu menjadi penyeimbang bagi acara yang tidak mendidik di televisi komersial. TVRI diperlukan agar mengambil peran dalam membangun jati diri bangsa dan berharap TVRI sebagai Lembaga Penyiaran Publik dapat mempertahankan diri di tengah kompetisi dunia penyiaran yang mengejar rating. "Kita berharap TVRI sebagai Lembaga Penyiaran Publik dapat mempertahankan diri di tengah

${ }^{8}$ Ibid. 
kompetisi dunia penyiaran yang mengejar rating. 9

Menkominfo berharap LPP TVRI dapat menjadi penyeimbang bagi acaraacara yang tidak mendidik dan provokatif yang berpotensi merusak karakter bangsa. Ia mencontohkan, konten-konten berbau kekerasan dan pornografi saat ini banyak ditayangkan di beberapa media penyiaran.Tifatul juga mengimbau televisi swasta untuk turut serta berperan dalam membangun karakter bangsa. Pemerintah sampai saat ini telah meremajakan 70 transmisi TVRI dari dana APBN dan bantuan dari Spanyol.

Persoalannya tidak mudah mengubah persepsi pemerintah yang melihat APBN sebagai dana Pemerintah. Persepsi APBN sebagai dana pemerintah ini juga menjangkiti kalangan masyarakat sipil dan internal TVRI sendiri. Persepsi yang menghegemoni ini kemudian melanggengkan cara berpikir yang hierarkhis tentang TVRI, yang menempatkan TVRI di bawah koordinasi Kementerian Komunikasi dan Informasi, yang menempatkan TVRI sebagai organ pemerintah meskipun bertentangan dengan status TVRI sebagai lembaga penyiaran publik sebagaimana diatur dalam UU Penyiaran No 32/2002.

\footnotetext{
9"'Tifatul: TVRI Mampu jadi

Penyeimbang!'Kompas.com, 21 Desember 2010, 17:34 WIB. Juga bisa dilihat pada arsip video siaran langsung peresmian pemancar TV digital LPP TVRI di Jakarta, Batam dan Surabaya di Auditorium LPP TVRI Senayan Jakarta, Selasa (21/12/2010).
}

Pemikiran untuk mengembalikan status TVRI, RRI dan Antara sebagai instrumen politik pemerintah menunjukkan belum sepenuhnya terjadi transformasi dari pola pikir yang otoritarian menuju pola pikir yang demokratis tentang fungsi dan kedudukan pers dan penyiaran. Pola pikir pemangku otoritas dalam organisasiakan selalu membayangkan dan mencitacitakan bahwa pemerintah harus memiliki media sendiri sebagai instrumen sosialisasi, diseminasi informasi dan propaganda politik. Pola pikir demokratik akan selalu tegas menyatakan bahwa urusan pers dan penyiaran adalah urusan publik, maka porsi terbesar untuk pengaturan dan pengendaliannya harus diserahkan kepada publik atau perwakilannya (Sudibyo, 2009: 224).

Dalam negara yang demokratik, tidak relevan lagi jika pemerintah memiliki media yang berfungsi politisideologis meskipun tidak berarti pemerintah tidak boleh mempunyai lembaga penyiaran. Konsentrasi negaranegara yang sistem demokrasinya sudah relatif baik adalah pemberdayaan publik, melalui upaya pemerintah untuk mendukung tumbuh kembangnya Lembaga Penyiaran Publik dan Komunitas, atas konsep: dari publik, oleh publik, dan untuk publik (Gazali, 2002:58). Lembaga Penyiaran Pemerintah fungsinya sebagai voice of government yang diagendakan sesuai 
dengan kepentingan pemerintah termasuk pencitraan atas kekuasaannya.

Kalau dicermati, siaran-siaran Lembaga Penyiaran Pemerintah ini malah ditujukan untuk penyiaran ke luar negeri tidak untuk konsumsi domestik seperti Voice of America (Amerika Serikat) yang memancar ke berbagai negara dan menyuarakan pemerintahan Amerika begitu pula Deutche Welle (Jerman). Untuk kepentingan dalam negeri, dalam konteks kehumasan, tentu pemerintah boleh menyampaikan visi dan misi serta kebijakannya kepada rakyat. Namun, menurut Gazali, justru puncak efektifitasnya adalah ketika pemerintah membiarkan masyarakat, mulai dari lapisan akar rumput mengangkat dan membahas isu-isunya sendiri. Kemudian, publik menginterpretasi dan memaknai kebijakan yang terkait dengan masalah mereka serta dihadiri pejabat publik yang mencoba mengagendakan penyelesaian bersama publik (Gazali, 2002: 59). Oleh karena itu, menjadi sebuah ironi bahwa di satu sisi Indonesia telah tiga belas tahun mentransformasikan diri dari rezim otoriter menuju rezim demokratik, tapi kecenderungan cara-pandang otoritarian masih menggayut dalam Lembaga Penyiaran Publik.

Pemikiran untuk mengembalikan status TVRI, RRI, dan Antara sebagai instrumen politik pemerintah sepertinya menunjukkan kegalauan terhadap praktek kebebasan pers yang berimbas kepada munculnya citra negatif tentang pemerintah. Pemerintah merasa sangat terpojok dengan kritisisme media dalam kasus "Cicak vs Buaya”, kontroversi Bank Century, Gurita Cikeas dan lain-lain. Pemerintah tidak melakukan strategi untuk meng-counter atas kritisisme media itu sehingga gagasan untuk menfungsikan kembali TVRI, RRI, dan Antara sebagai instrumen politik pemerintah, sebagaimana terjadi di masa lalu, dimunculkan. ${ }^{10}$

Pernyataan Wakil Presiden Boediono dan Menkominfo Tifatul Sembiring untuk menyinergikan TVRI, RRI dan Antara, serta untuk menjadikan TVRI sebagai media yang membantu pemerintah menimbulkan kontroversi publik dan dianggap sebagai sesuatu yang kontraproduktif bagi kebebasan pers dan demokratisasi penyiaran. Kalangan TVRI, RRI, dan Antara sendiri banyak yang tidak tahu dengan ide tersebut. Kontroversi belum mereda, publik dihadapkan pada perkembangan rencana pemerintah untuk mengembalikan TVRI (dan RRI) sebagai lembaga penyiaran milik pemerintah, yakni dengan dilansirnya secara resmi Rancangan Peraturan Pemerintah (RPP) tentang Lembaga Penyiaran Publik. Dalam RPP ini, pemerintah merencanakan beberapa langkah, antara lain: (1) Pembubaran TVRI dan RRI; (2) Penyatuan fungsi lembaga penyiaran publik televisi dan

\footnotetext{
${ }^{10}$ Lihat Pernyataan Sikap Koalisi Peduli Pers dan Penyiaran (KP3) Menolak Pembubaran TVRI dan RRI, dipublikasikan pada 12 Januari 2010
} 
radio ke dalam satu wadah: Radio Televisi Republik Indonesia/RTRI;

Penempatan Pemerintah sebagai pembina lembaga penyiaran publik; (4) Legalisasi otoritas pemerintah dalam mengintervensi kebijakan-kebijakan terkait dengan lembaga penyiaran publik: pemilihan direksi, dewan pengawas, budgeting dan lain-lain.

Dengan langkah-langkah tersebut, RPP tentang Lembaga Penyiaran Publik itu menjauhkan peluang publik untuk memiliki lembaga penyiaran dengan sensibilitas kerukunan dan kemajemukan sosial. Perubahan status sebagaimana tergambar dalam RPP di atas akan menjadikan TVRI dan RRI sebagai lembaga penyiaran di bawah kendali pemerintah lagi. Jika TVRI dan RRI menjadi lembaga di bawah kendali pemerintah, maka perhatian TVRI dan RRI pertama dan terutama adalah menyuarakan kepentingan-kepentingan pemerintah, menjadi instrumen komunikasi politik pemerintah. Di sini, sulit mengharapkan TVRI dan RRI untuk tetap peduli terhadap isu-isu kerukunan dan kemajemukan. Sebagaimana sulit mengharapkan lembaga penyiaran komersial yang berorientasi kepada pasar untuk peduli terhadap isu yang sama.

Bagi beberapa pihak, rencana pemfungsian kembali TVRI dan RRI sebagai penyiaran milik pemerintah itu melanggar prinsip dasar lembaga penyiaran publik dalam sistem penyiaran yang demokratis ${ }^{11}$. Sejak adanya UU Penyiaran No 32/2002, bangsa Indonesia sudah meninggalkan sistem penyiaran otoriter, yang memungkinkan penggunaan media sebagai instrumen propaganda pemerintah. Oleh karena itu, upaya atau rencana untuk mengembalikan TVRI dan RRI sebagai media milik pemerintah menjauhkan prinsip penyiaran demokratis. Namun masalahnya, pikiran untuk menjadikan TVRI dan RRI sebagai instrumen politik pemerintah itu memang cenderung ada di kalangan pemerintah.

Ini adalah pengkhianatan terhadap cita-cita demokratisasi penyiaran yang harus dilawan. Kalau memang ingin mempunyai media, mengapa pemerintah tidak membikin saja semacam Voice of America, yang memang milik pemerintah dan menyuarakan kepentingan pemerintah. Itu pun disiarkan ke luar negeri, bukan ke dalam negeri. Perlu ditegaskan, lembaga penyiaran publik, TVRI dan RRI, itu milik publik, bukan milik pemerintah. Bisa dikatakan keduanya milik negara, tapi dalam pengertian yang lebih dekat ke milik publik, bukan milik pemerintah. ${ }^{12}$

Pada akhirnya, pemikiran untuk mengembalikan status TVRI, RRI, dan Antara sebagai instrumen politik pemerintah menjadi kontraproduktif bagi pelembagaan penyiaran publik. Fungsi penyiaran publik dimanapun adalah menjalankan keutamaan-keutamaan

\footnotetext{
${ }^{11}$ Wawancara Amir Effendy Siregar, 7 November 2011.

${ }^{12}$ Amir Effendi Siregar, ibid.
} 
publik, yakni pendidikan kewargaan, ruang-publik budaya, pemberdayaan sosial-ekonomi. UU Penyiaran No 32/2002 menegaskan TVRI-RRI adalah lembaga penyiaran publik yang bersifat independen, netral, dan berfungsi memberikan layanan untuk kepentingan masyarakat.

Dari perspektif birokrasi organisasi, gagasan penggabungan TVRI, RRI serta Antara dapat dilihat sebagai upaya maksimalisasi kinerja kerja organisasi dalam konteks politik yang diaplikasikan dengan pola clear-cut hierarchy of authority. Maksimalisasi kinerja organisasi dapat dicapai dengan melakukan ekspansi, efisiensi dan konvergensi. Namun bila dilihat dari cara pandang ekonomi politik, hal tersebut dapat dijelaskan dengan terminologi spasialisasi, yaitu hal yang berkaitan dengan upaya pemilik media untuk melakukan "pembesaran” lingkup operasi demi menjangkau khalayak yang lebih luas dengan cara yang efektif dan efisien. Media selalu terdorong, dengan alasan ekonomi atau politik, untuk memperlebar rentang usahanya, mendiversifikasi produk, mengefisienkan operasional kerja (Mosco,1996 dalam Sudibyo, 2012). Logika spasialisasi ini juga yang mendasari gagasan penyatuan TVRI, $R R I$ dan Antara. Titik tolaknya sekali lagi adalah pandangan pemerintah bahwa media-media yang didukung pendanaan APBN adalah media milik pemerintah.
Dalam cara-pandang ini, Pemerintah secara taken for granted menempatkan diri sebagai pemilik TVRI, RRI, dan Antara, meskipun UU Penyiaran No 32/2002 telah mengubah TVRI dan RRI menjadi lembaga penyiaran publik. Pemerintah kemudian berpikir untuk mengambil alih ketiga media itu, dan akan lebih mudah bagi pemerintah untuk mengendalikan dan mengarahkan media itu sesuai dengan keinginan pemerintah jika ketiganya disatukan ke dalam satu lembaga baru. Dengan lembaga baru ini, pemerintah juga berharap dapat melakukan penggalangan opini publik, diseminasi informasi dan fungsi penerangan yang sekaligus menjangkau pemirsa televisi, pendengar radio, pembaca media cetak dan pengakses media online. Keterbatasan ruang dan waktu yang dihadapi pemerintah dalam berkomunikasi dengan publik coba diatasi dengan menyinergikan tiga jenis media yang berbeda yang kebetulan mendapatkan dukungan dana dari APBN.

Dengan logika maksimalisasi kerja organisasi melalui relasi antarorganisasi, Pemerintah kemudian berencana mengonsolidasikan TVRI, RRI, dan Antara. Dari sisi ekonomi politik, ada dua jenis konsolidasi yang direncanakan pemerintah dalam RPP Lembaga Penyiaran Publik. Pertama, konsolidasi horisontal dalam arti penyatuan tiga lembaga media yang mendapatkan dukungan dana dari APBN ke dalam satu manajemen. Kedua, konsolidasi vertikal 
dalam artian lembaga baru hasil penyatuan tiga lembaga media ini akan berposisi subordinat sebagai organ penggalangan opini publik dan diseminasi informasi bagi pemerintah. Rencana Pemerintah untuk mengakuisisi dan memerger ketiga lembaga media ini sangat bisa dipahami. TVRI, RRI dan Antara adalah institusi media yang lingkupnya nasional, mempunyai sejarah yang panjang dan secara politis cukup signifikan pengaruhnya. Oleh karena itu, jika ketiga media ini disatukan dalam satu lembaga baru yang menjalankan fungsi kehumasan, akan sangat membantu pemerintah dalam melakukan counterdiscourse terhadap pers komersial serta untuk menjelaskan program-program pemerintah kepada publik.

Dengan gagasan penggabungan TVRI, RRI, dan Antara, pemerintah tidak lagi memproyeksikan ketiga lembaga ini sebagai lembaga yang mandiri dan mempunyai spesifikasi peran tertentu sebagaimana yang selama ini telah berlangsung. Ketiga lembaga ini diproyeksikan sebagai media yang berada dalam kesatuan manajemen operasional dan kesatuan tujuan politik, atau sebagai "tritunggal" media yang menyuarakan kepentingan kekuasaan. Pemerintah berusaha melakukan pembesaran lingkup institusional ketiga media yang mendapatkan dukungan dana dari APBN dan yang oleh karenanya dipersepsi sebagai media milik pemerintah.
Dengan praktik clear-cut hierarchy of authority, pemerintah berusaha melakukan pemusatan kontrol terhadap TVRI dan RRI yang menurut UU Penyiaran No 32/2002 adalah lembaga penyiaran yang independen dan mandiri, serta terhadap Antara yang sesungguhnya justru telah terlebih dahulu diproyeksikan sebagai korporasi yang lebih bersifat profit oriented. Dalam konteks ini, ada dua hal yang bertolak belakang, yakni antara amanat yang tertera dalam teks undang-undang dan inplementasi. UU Penyiaran No 32/2002 merupakan bentuk campur tangan politik untuk meniadakan monopoli kepemilikan media. Namun, pemerintah justru melakukan kontrol atas kebijakan dan operasionalisasi TVRI dan RRI yang sesungguhnya telah bertransformasi menjadi lembaga penyiaran publik.

Rencana untuk mengembalikan status TVRI, RRI, dan Antara sebagai instrumen politik pemerintah serta harapan agar TVRI dapat membantu pemerintah dalam mengimbangi kritisisme pers umum, menunjukkan bahwa dalam birokrasi pemerintahan, belum sepenuhnya terjadi transformasi dari paradigma berpikir yang otoritarian menuju paradigma berpikir yang demokratis-partisipatoris tentang fungsi dan kedudukan media dalam relasinya dengan kekuasaan. Paradigma berpikir otoritarian selalu berangkat dari asumsi tentang pers sebagai instrumen pemerintah dalam menjalankan fungsi- 
fungsi komunikasi dan diseminasi informasi. Sementara paradigma berpikir demokratik-partisipatoris, selalu menempatkan pers di luar sistem kekuasaan, bahkan berhadap-hadapan dengan kekuasaan. Pers adalah instrumen masyarakat untuk menjalankan fungsi kontrol terhadap bentuk-bentuk kekuasaan, baik kekuasaan politik, ekonomi maupun budaya.

Tabel 1. Perbedaan Cara Pandang Tentang TVRI

\begin{tabular}{lll}
\hline \multicolumn{1}{c}{$\begin{array}{c}\text { Cara pandang unsur } \\
\text { pemerintah }\end{array}$} & \multicolumn{1}{c}{ Unsur } & \multicolumn{1}{c}{$\begin{array}{c}\text { Cara pandang } \\
\text { Unsur publik }\end{array}$} \\
\hline TVRI didanai dengan APBN & DANA & TVRI didanai dengan APBN \\
APBN adalah dana pemerintah & APBN & APBN adalah dana public \\
$\begin{array}{l}\text { Maka TVRI adalah televisi milik } \\
\text { pemerintah }\end{array}$ & KEPEMILIKAN & $\begin{array}{l}\text { Maka TVRI adalah televisi } \\
\text { milik publik }\end{array}$ \\
$\begin{array}{l}\text { TVRI perlu berpihak kepada } \\
\text { kepentingan pemerintah }\end{array}$ & KEBERPIHAKAN & $\begin{array}{l}\text { TVRI bersifat independen, } \\
\text { netral, berpihak kepada } \\
\text { kepentingan public }\end{array}$ \\
$\begin{array}{l}\text { Penggabungan TVRI, } R R I, \\
\text { Antara untuk alasan efisiensi } \\
\text { dan politik: membantu } \\
\text { pemerintah untuk menghadapi }\end{array}$ & ALASAN & $\begin{array}{l}\text { Penggabungan TVRI dan } R R I \\
\text { dimungkinkan sejauh }\end{array}$ \\
kritik pers terhadap pemerintah & PENGGABUNGAN & $\begin{array}{l}\text { lasannya adalah efisiensi, } \\
\text { tanpa mengubah karakter dan } \\
\text { sejarah masing-masing, } \\
\text { sementara penggabungan } \\
\text { dengan Antara tidak } \\
\text { dimungkinkan karena Antara } \\
\text { bukan lembaga penyiaran } \\
\text { publik. }\end{array}$ \\
\hline & & Sumber: adopsi berbagai referensi \\
& &
\end{tabular}

\section{Intervensi Politik dan Ketergantungan TVRI}

TVRI masih terbebani sebagai televisi milik pemerintah, yang selalu menjadi sasaran intervensi politik dan menjadi ajang perebutan kepentingan unsur-unsur kekuasaan. Intervensi politik selalu terjadi terhadap TVRI di masa lalu ketika TVRI secara langsung berada di bawah kontrol Departemen Penerangan. Intervensi politik itu ternyata tidak dapat dihapuskan sepenuhnya ketika status TVRI berubah menjadi lembaga penyiaran publik. Perbedaannya, jika di masa Orde Baru intervensi politik terhadap TVRI bersifat langsung dan memusat kepada campur tangan Departemen Penerangan, intervensi politik terhadap TVRI pada masa reformasi bersifat tidak langsung, di bawah permukaan dan dapat muncul dari beberapa penjuru: pemerintah, DPR RI, Presiden atau dari Partai Politik.

Setiap pergantian Dewan Direksi atau Dewan Pengawas TVRI muatan politiknya sangat kuat. Partai-partai politik kelihatan saling berebut untuk menempatkan kadernya atau orang 
dekatnya dalam jabatan strategis TVRI. TVRI diperebutkan sebagaimana partaipartai memperebutkan pemangku jabatan-jabatan strategis kementerian, BUMN dan lain-lain. Sikap DPR RI terhadap TVRI menjadi berubah-ubah dan tidak konsisten karena dalam DPR RI sendiri muncul sikap dan kepentingan yang berbeda-beda terhadap kedudukan TVRI. Hal ini tentu saja tidak kondusif bagi perkembangan TVRI kecuali partaipartai benar-benar mempunyai konsep yang jelas untuk mengembangkan TVRI sebagai penyiaran publik, dan tidak sekedar memperebutkan jabatan strategis TVRI dengan pertinbangan kepentingan ekonomi atau politis tertentu.

Sikap intervensionis DPR RI terhadap TVRI menunjukkan bahwa DPR RI juga menggunakan cara-pandang yang struktural dan hierarkhis terhadap TVRI, sebagaimana hal yang sama juga muncul pada pemerintah. DPR RI menempatkan dirinya lebih dari sekedar sebagai pengambil kebijakan, tetapi juga sebagai pihak yang "berjasa" terhadap TVRIkarena menjadi pihak yang menyetujui anggaran tahunan TVRI, memilih dan memutuskan Dewan Pengawas TVRI. DPR RI merasa mempunyai andil terhadap operasionalisasi TVRI dan selalu melihat TVRI sebagai pihak yang tergantung kepada kebijakan DPR RI. Dalam konteks relasi ketergantungan ini, muncul persepsi bahwa sudah selayaknya jika
DPRRI bersikap intervensionis terhadap TVRI.

Oleh karena itu, menjadi bukan suatu kesalahan jika DPR RI bersama pemerintah membicarakan kemungkinan penggabungan TVRI, RRI dan Antara tanpa melibatkan pihak internal TVRI. Dalam cara pandang yang hierarkisstruktural ini, TVRI ditempatkan dalam posisi yang sub-ordinat, baik terhadap pemerintah yang merasa telah mendanai TVRI, juga kepada DPR RI yang merasa sebagai penentu kebijakan tentang TVRI. Dari sisi teori strukturasi, tampak pola relasi yang bukan antara wakil rakyat sebagai pengambil kebijakan dan lembaga penyiaran publik, tetapi pola ketergantungan institusi politik yang secara hierarkhis lebih tinggi dengan sebuah lembaga penyiaran yang secara hierarkhis lebih rendah dan menanggung beban politik masa lalu sebagaimana dijelaskan di atas.

UU Penyiaran No. 32/2002 memberikan porsi yang besar bagi DPR RI untuk mengontrol TVRI. DPR RI dapat menjalankan fungsi budget dan fungsi pengawasan terhadap TVRI. DPR RI yang menentukan apakah UU Penyiaran No 32/2002 perlu diamandemen atau tidak, dan jika terjadi amandemen seperti apa bentuknya. DPR RI pula yang menentukan apakah akan dirumuskan undang-undang tersendiri tentang lembaga penyiaran publik atau tidak. DPR RI juga dapat memanfaatkan politik budget untuk memaksa atau 
menggiring jajaran Dewan Pengawas atau

Direksi untuk melakukan langkahlangkah tertentu. DPR RI juga dapat setiap saat meminta laporan dan penjelasan TVRI dalam rangka fungsi pengawasan badan publik. Lebih dari itu, DPR RI mempunyai otoritas untuk menyeleksi dan memilih Dewan Pengawas TVRI.

Bila dikaitkan dengan dengan Teori Birokrasi maka kondisi di atas dapat dipahami dalam konsep clear-cut hierarchy of authority, yang menjelaskan bahwa aktivitas dalam organisasi terdistribusi sebagai "tugas". Birokrasi memiliki struktur yang mirip dengan piramida dimana pemegang otoritas tertinggi berada pada posisi teratas dan memiliki wewenang atas kebijakan. Hal tersebut memang berbeda dengan apa yang dilihat dari kaca mata kritikal yang memandang bahwa praktik seperti di atas bias karenamenjadi sarana mencapai kepentingan.Inilah persoalan politik TVRI, yakni ketergantungan besar terhadap DPR RI. Sementara dalam praktiknya, DPR RI itu sendiri lebih menunjukkan keinginan dan kepentingan partai-partai politik besar. Tentang hal ini, Sumita Tobing menyatakan keprihatinan atas kondisi perpolitikan di Indonesia dewasa ini yang mempengaruhi pengelolaan TVRI.

UU Penyiaran, yang mengesahkan LPP (lembaga penyiaran publik) dan Dewan Pengawas LPP di fit and proper test oleh DPR RI. Karena DPR RI itu instansi politik, semuanya jadi politis dan dipolitikkan. Di sisi lain, sistem politik kita sudah dihinggapi”bajing loncat” yang memungkinkanpolitisi itu pindah-pindah, dari Golkar ke Demokrat, dari Demokrat pindah ke partai lain, dan seterusnya sehingga tidak ada ideologi. Padahal, mereka yang menentukan Dewan Pengawas TVRI, menentukan KPI, KPU, Jaksa Agung, Kapolri. ${ }^{13}$

Ketua Pansus RUU Penyiaran 1999-2002, Paulus Widiyanto, menyatakan yang diberi tugas menentukan Dewan Pengawas adalah Negara dan uji kepatutan dan kelayakan dilakukan oleh DPR RI RI sebagai representasi keterwakilan publik dan merupakan bentuk konkret dari sebuah sistem demokrasi ${ }^{14}$.Menurut Ashadi Siregar, DPR RI sebenarnya merupakan representasi dari civil society. Untuk memperbaiki kondisi sosial-politik, civil society harus turut mengendalikan penyelenggaraan Negara, dan, oleh karena itu, mereka harus masuk ke DPR RI. Namun, kaum pemodal juga ingin memperjuangkan kepentingannya secara politik melalui DPR RI sehingga lembaga ini menjadi representasi dari dua domain sekaligus, domain civil society dan domain kapitalisme pasar. Kedua kepentingan ini kemudian berebut posisi di DPR RI. DPR RI merupakan arena interaksi dan perabutan antar keduanya.

\footnotetext{
${ }^{13}$ Wawancara Sumita Tobing, 12 Oktober 2011.

${ }^{14}$ Wawancara Paulus Widiyanto, 1 November 2011
} 
Rebutan pengaruh civil society dan para kapitalis terjadi di DPR RI terus menerus. Sehingga setiap kali ada undang-undang segala macem itu selalu untuk menguntungkan kapitalisme pasar atau civil society. Kalau misalnya DPR RInya lebih memenangkan kepentingan kapitalisme pasar, ya sudah civil society harus berjuang lebih lanjut, menekan parlemen untuk mengubahnya, atau berjuang dalam pemilu selanjutnya agar calon dari civil society yang berhasil masuk parlemen, bukan para pembela kepentingan kapitalis. ${ }^{15}$

Terkait dengan masalah dominannya peran DPR RI dalam pelembagaan penyiaran publik, perlu diperhatikan penjelasan dari Paulus Widiyanto selaku Ketua Pansus RUU Penyiaran 1999-2002. Paulus menjelaskan, pada akhirnya, Pansus RUU Penyiaran waktu itu tetap memutuskan yang melakukan fit and propertest calon anggotaDewan Pengawas TVRI-RRI sebagai lembaga penyiaran publik adalah DPR RI. Inilah pilihan yang paling mungkin dari sisi pendekatan hukum dan teori politik. Memang waktu itu, ada ide agar pemilihan Dewan Pengawas lembaga penyiaran publik dilakukan oleh tim adhoc yang anggotanya dipilih dari kalangan perguruan tinggi. Mereka kemudian melakukan seleksi dan fit and proper test calon Dewan Pengawas dengan kriteria yang sudah ditentukan. Tetapi menurut Paulus Widianto,

\footnotetext{
15 Wawancara Ashadi Siregar, 7 November 2011.
}

persoalannya adalah sejak kapan dan dengan dasar apa kita dapat melakukan penyeleksian oleh tim adhoc?

Kita harus konsisten dengan sistem demokrasi yang sudah baku dan menjadi komitmen bersama. Meskipun ada keraguan independensi Dewan Pegawas terhadap DPR RI, kenyataannya DPR RI adalah lembaga keterwakilan masyarakat yang paling representatif, sebagai hasil konkrit dari sistem demokrasi. ${ }^{16}$

Sikap intervensionis DPR RI terhadap TVRI juga dapat dilihat dalam konteks hubungan DPR RI dengan Dewan Pengawas TVRI. Sebagai contoh, pada akhir Oktober 2010, tiba-tiba pimpinan DPR RI RI meminta Dewan Pengawas TVRI mengundurkan diri tanpa alasan yang cukup jelas, dan tanpa preseden yang masuk akal. ${ }^{17}$ Persoalannya adalah sikap DPR RI ini adalah yang sangat serius dan berpotensi melanggar UU Penyiaran No. 32/2002. Sayangnya, pers kurang memperhatikan masalah ini.

Dalam UU Penyiaran dan PP tentang Lembaga Penyiaran Publik tidak ada klausul yang menyatakan bahwa pimpinan DPR RI dapat memberhentikan secara langsung Dewan Pengawas TVRI. Dewan Pengawas TVRI pertama-tama dipilih oleh Komisi I DPR RI melalui proses fit and proper test, lalu disahkan melalui Sidang Paripurna DPR RI.

\footnotetext{
${ }^{16}$ Wawancara Paulus Widiyanto, 1 November 2011.

17 Lihat "TVRI Kembali Jadi Corong

Pemerintah?”, Tempointeraktif. Diakses 29 Oktober 2010
} 
Setelah disahkan DPR RI, Dewan Pengawas kemudian secara resmi diangkat oleh Presiden. Demikian juga sebaliknya, proses penghentian Dewan Pengawas TVRI harus dimulai dengan usulan yang datang dari Komisi I DPR RI, lalu dimintakan persetujuan pada Rapat Paripurna DPR RI, sebelum kemudian diteruskan pengajuannya kepada Presiden. Dengan catatan, penghentian ini dapat dilakukan jika Dewan Pengawas terbukti melakukan kesalahan yang berat.

Sementara hingga Oktober 2010, praktis tidak ada kesalahan berat yang dilakukan Dewan Pengawas TVRI meskipun Dewan Pengawas terlibat beberapa masalah dengan kelompok karyawan TVRI dan bersilang pendapat dengan Komisi I DPR RI. Menghadapi permintaan mundur itu, Anggota Dewan Pengawas TVRI kemudian meminta alasan tertulis kepada pimpinan DPR RI. Namun, Dewan Pengawas TVRI tidak memperoleh jawaban yang tegas dan tertulis tentang hal tersebut. DPR RI merasa tidak perlu memberikan penjelasan tentang permintaannya tersebut. Dalam hal ini, DPR RI memposisikan dirinya secara hierarkhis lebih tinggi daripada TVRI sehingga dapat bertindak secara sepihak terhadap TVRI, bahkan jika perlu dengan menegasikan keberadaan UU Penyiaran No. 32/2002. Tampak pula, hubungan yang diinginkan DPR RI dengan TVRI, yakni hubungan yang bersifat struktural yang menempatkan TVRI sebagai subordinat.

Bentuk-bentuk intervensi dan relasi strukural-hirarkhis yang direpresentasikan oleh DPR RI tersebut diperumit oleh intervensi pemerintah dalam memperpanjang tugas direksi. Ketika Dewan Pengawas periode 20062011 ${ }^{18}$ tidak diperpanjang masa tugasnya dan Direksi LPP TVRI telah habis pula masa tugasnya, Pemerintah melakukan spasialisasi kebijakan dengan memperpanjang tugas Direksi LPP TVRI periode 2006-2011 melalui Keputusan Menteri Komunikasi dan Informatika RI Nomor 377/KEP/ M.KOMINFO/o8/2011 tertanggal 23 Agustus 2011 tentang Perpanjangan Masa Kerja Dewan Direksi Lembaga Penyiaran. Keputusan Menteri Komunikasi itu jelas melanggar UU Penyiaran Nomor 32/2002 karena Publik TVRIpasal 14 ayat 7 menyebutkan bahwa dewan direksi diangkat dan ditetapkan oleh Dewan Pengawas dan pasal 19 ayat 3 berbunyi dewan direksi diangkat dan diberhentikan oleh Dewan Pengawas. Menurut pasal 7 huruf d, Dewan

\footnotetext{
${ }^{18}$ Berdasarkan wawancara dengan Hazairin Sitepu, Ketua Dewan Pengawas TVRI, DPR RI sebenarnya telah berkali-kali menekan Dewan Pengawas untuk mengganti keseluruhan direksi dan ketika permintaan itu tidak dipenuhi Dewan Pengawas maka kalangan DPR meminta agar Direktur Utamanya saja yang diganti. Direktur Utama memang pada akhirnya diganti, tapi Dewan Pengawas tidak memilih nama yang disodorkan DPR. Hal ini membuat ketegangan terus-menerus antara DPR dan Dewan Pengawas yang berujung pada pengunduran kolektif Dewan Pengawas TVRI, dan, pada akhirnya, mendorng intervensi pemerintah lebih lanjut.
} 
Pengawas mempunyai tugas mengangkat dan memberhentikan dewan direksi serta pada pasal 23 ayat 2 disebutkan calon dewan direksi terpilih diangkat melalui surat keputusan Dewan Pengawas.

Dalam konsiderans "menimbang" pada Keputusan Menteri Komunikasi itu, dirujuk hasil rapat kerja Komisi I DPR dengan Menteri Komunikasi pada 16 Agustus 2011. Hasil rapat butir 2 menyatakan bahwa Komisi I DPR dan pemerintah bersepakat bahwa pemerintah memperpanjang masa kerja dewan direksi TVRI sampai terbentuknya Dewan Pengawas TVRI periode 20112016, yang akan mengangkat direksi baru. Di sini, Komisi I DPR dan Pemerintah kemudian melanggar undang-undang. Catatan hasil rapat kerja bukanlah produk hukum, sementara yang dilanggar pemerintah jelas produk hukum, yaitu Undang-Undang Penyiaran.

Menurut ketentuan, pada pasal 27 ayat 3, selain Dewan Pengawas dan direksi, pihak lain manapun dilarang turut campur dalam kebijakan operasional siaran TVRI. Memperpanjang masa kerja direksi sama dengan mengangkat direksi. Direksi adalah lembaga operasional yang menangani langsung pengelolaan TVRI. ${ }^{19}$ Komplikasi hukum perpanjangan masa tugas Direksi LPP TVRI juga sebetulnya memiliki potensi yang cukup berat sesuai Hukum

\footnotetext{
${ }^{19}$ S. Sinansari Ecip“Perhatikan DPR, Menteri Langgar Undang-Undang”, Koran Tempo, $29 / 11 / 2011$
}

Administrasi Negara karena Menkominfo cq Pemerintah tidak memiliki kewenangan yang cukup untuk melakukan hal tersebut, sehingga akan berimbas bahwa semua keputusan yang diambil oleh Direksi LPP TVRI pada masa tersebut adalah cacat hukum. Dalam situasi semacam ini, Direksi tidak dapat menandatangani perjanjian, tidak bisa mengeluarkan Surat Keputusan, dan yang tidak kalah fatal, tidak dapat melakukan penggajian pegawai.

Lebih menarik dikaji adalah, secara hukum, DPR RI tidak akan dapat dimintai pertanggungjawaban atas tindakan Kemenkominfo tersebut, karena seperti telah dijelaskan di atas Hasil Rapat Kerja DPR-Pemerintah bukanlah sebuah produk hukum yang dapat dijadikan landasan untuk melakukan suatu tindakan hukum.

\section{Penutup}

Tulisan ini berusaha mengupas persoalan-persoalan politik dan struktural yang menghimpit. Berdasarkan analisis di atas, lemahnya transformasi TVRI menjadi lembaga penyiaran publik pada dasarnya berangkat dari persoalanpersoalan politik dan kultural. Pada satu sisi, pemerintah masih sangat mengharapkan LPP TVRI menjadi lembaga penyiaran pemerintah yang mampu menjadi penyeimbang bagi lembaga penyiaran swasta yang terlampau memojokkan pemerintah. 
Sementara itu, dari kalangan DPR, mereka merasa sangat berjasa kepada TVRI, dan karenaya dalam setiap pergantian Dewan Direksi atau Dewan Pengawas TVRI, partai-partai politik kelihatan saling berebut untuk menempatkan kadernya atau orang dekatnya dalam jabatan strategis TVRI. TVRI diperebutkan sebagaimana partaipartai memperebutkan pemangku jabatan-jabatan strategis kementerian, BUMN dan lain-lain. Dalam situasi semacam ini, imajinasi lembaga penyiaran publik dalam pengertian sesungguhnya akan sulit dilakukan. Ini belum termasuk persoalan internal yang menghimpit TVRI.

Oleh karena itu, mentransformasikan TVRI menjadi lembaga penyiaran publik tidak akan terlaksana sejauh pemerintah dan unsurunsur politik selalu mendekati restrukturisasi TVRI dengan kepentingan-kepentingan yang partikular. Menurut Sudibyo (2004:301) ${ }^{20}$, idealisasi penyiaran publik sebagai pengemban keutamaan-keutamaan publik mutlak menuntut pembebasan TVRI dari bebanbeban untuk menopang rasionalitas subsistem birokrasi negara atau subsistem pasar.

\footnotetext{
${ }^{20}$ Juga lihat Ashadi Siregar dalam Media Penyiaran Publik Catatan Ringkas. Makalah untuk Forum Diskusi Publik Kebijakan Pengembangan TVRI sebagai TV Publik, Dewan Pengawas TVRI,Jakarta 20 Desember 2006.
}

\section{Daftar Pustaka}

Ecip, S. Sinansari. "Perhatikan DPR, Menteri Langgar UndangUndang”, Koran Tempo, 29/11/2011.

Gazali, Effendi. 2002. Penyiaran Alternatif, tapi Mutlak: Sebuah Acuan tentang Penyiaran Publik dan Komunitas, Jakarta: Jurusan Ilmu Komunikasi FISIP Universitas Indonesia.

Kitley, Philip.2001. Konstruksi Budaya Bangsa di Layar Kaca. LSPP, ISAI dan PT Media Lintas Inti Nusantara.

Moelyono, Djokosantoso. 2004. Reinvensi $B U M N$, Jakarta: Komputindo Siregar, Ashadi, Media Penyiaran Publik Catatan Ringkas. Makalah untuk ForumDiskusi Publik Kebijakan Pengembangan TVRI sebagai TV Publik, Dewan Pengawas TVRI, Jakarta, 20 Desember 2006.

Sudibyo, Agus. 2004. Ekonomi Politik

Media Penyiaran. LKIS \& ISAI,

Yogyakarta \& Jakarta .2001. Menyingkap Media

Penyiaran: Membaca Televisi, Melihat Radio. Yogyakarta: LP3Y. 2005. Republik Tanpa

Ruang Publik: Catatan dari Nias, Meulaboh, dan Merauke. Ire Press. 
2009. "Rekonsiliasi Ruang

Publik: Anomali Penyiaran Pasca 2001". Jurnal Lembaga Penelitian, Pendidikan, dan Penerangan Ekonomi dan Sosial (LP3ES), Prisma, No. 1 vol 28. Pernyataan Sikap Koalisi Peduli Pers dan Penyiaran (KP3) Menolak Pembubaran TVRI dan $R R I$, dipublikasikan pada 12 Januari 2010.

Wawancara Sumita Tobing, 12 Oktober 2011.

Wawancara Paulus Widiyanto, 1 November 2011

Wawancara Ashadi Siregar, 7 November 2011.

Wawancara Amir Effendi Siregar, 7 November 2011.
"JK: TVRI Boleh Kritis Asal...", Inilah.com, 13 Agustus 2008, 17:36 WIB.

"Presiden Minta TVRI Jaga Netralitas", Tempointeraktif, 21 Desember 2010, 18:40 WIB

"TVRI Kembali Jadi Corong Pemerintah?" Tempointeraktif, 29 Oktober 2010, 08:01 WIB.

"Wapres : Dua Tahun Bagi Perbaikan Program TVRI", Antaranews, 24 Agustus 2008

"Boediono: Sinergi TVRI-Antara Imbangi Swasta" Vivanews, 14 Desember 2009 